\title{
HUBUNGAN ANTARA DUKUNGAN KELUARGA DAN PENGETAHUAN IBU BAYI DENGAN PEMBERIAN IMUNISASI HBo DI DESA IGIRKLANCENG KECAMATAN SIRAMPOG KABUPATEN BREBES TAHUN 2020
}

\author{
Laelatul Mubasyiroh \\ STIKes Brebes \\ ellaaxella@gmail.com
}

\begin{abstract}
Abstrak
Program imunisasi merupakan program yang memberikan sumbangan yang sangat bermakna dalam rangka menurunkan angka kesakitan dan angka kematian yang disebabkan oleh berbagai Penyakit yang Dapat Dicegah Dengan Imunisasi (PD3 I). Cakupan program imunisasi yang tinggi dengan kualitas program yang baik, terbukti mempercepat angka penurunan kesakitan dan angka kematian bayi (Depkes RI, 2003).

Dalam penelitian ini penulis menggunakan jenis penelitian Cross sectional dengan pendekatan korelasional. Adapun populasinya ibu bayi di Desa Igirklanceng berjumlah 43 orang. Pengambilan sampel secara total sampling, adapun variabel penelitian variabel bebasnya yaitu dukungan keluarga dan pengetahuan, variabel terikatnya yaitu pemberian imunisasi HBo. Instrumen yang digunakan berupa kuesioner. Data dalam penelitian ini menggunakan data primer dan sekunder.

Hasil penelitian dari 43 responden menunjukkan dukungan keluarga ibu bayi di Desa Igirklanceng Kecamatan Sirampog Kabupaten Brebes Tahun 2020 yang tidak mendukung yaitu 22 responden $(51,2 \%)$, dan yang mendukung yaitu 21 responden (48,8\%). Pengetahuan tentang imunisasi HBo ibu bayi di Desa Igirklanceng Kecamatan Sirampog Kabupaten Brebes Tahun 2020 dalam kategori baik 15 responden $(34,9 \%)$ dan kategori cukup yaitu 21 responden $(48,8 \%)$, dan yang berpengetahuan kurang yaitu 7 responden $(16,3 \%)$. Ada hubungan antara dukungan keluarga dengan keputusan pemberian imuniasasi HBo di Desa Igirklanceng Kecamatan Sirampog Kabupaten Brebes $(p=0,00063<\alpha(0,05)$. Ada hubungan antara pengetahuan dengan keputusan pemberian imuniasasi HBo di Desa Igirklanceng Kecamatan Sirampog Kabupaten Brebes tahun $2020(p=0,005<\alpha(0,05)$.
\end{abstract}


JOURNAL OF NURSING PRACTICE AND EDUCATION

VOL. 01 NO. 02, JUNI 2021

DOI: 10.34305/JNPE.V1I2.294
Ciptaan disebarluaskan di bawah

Lisensi Creative Commons Atribusi-

NonKomersial-BerbagiSerupa 4.0 Internasional.

\section{Pendahuluan}

\section{Latar Belakang}

Program Imunisasi merupakan program yang memberikan sumbangan yang sangat bermakna dalam rangka menurunkan angka kesakitan dan angka kematian yang disebabkan oleh berbagai Penyakit yang Dapat Dicegah Dengan Imunisasi (PD3 I). Cakupan program imunisasi yang tinggi dengan kualitas program yang baik, terbukti mempercepat angka penurunan kesakitan dan angka kematian bayi (Depkes RI, 2003).

Menurut Survei Kesehatan Rumah Tangga (1995), penyebab utama kematian bayi adalah ISPA, komplikasi perinatal dan diare. Pada tahun 2001 pola penyebab kematian bayi ini tidak banyak berubah dari periode sebelumnya yaitu sebab perinatal, kemudian diikuti diare, ispa dan tetanus neonatorum.

Penurunan Angka Kematian Bayi (AKB) dan penurunan Angka Kematian Balita (AKBA) merupakan salah satu prioritas pembangunan kesehatan, upaya ini tercantum dalam tiga program kesehatan nasional yaitu : program lingkungan sehat, perilaku sehat dan pemberdayaan masyarakat. Sebagai contoh dengan meningkatkan kembali posyandu, Perilaku Hidup Bersih dan Sehat (PHBS). Strategi dan upaya untuk menurunkan $\mathrm{AKB}$ dan
AKBA antara lain dengan pemberantasan penyakit menular, meningkatkan cakupan imunisasi dan penanggulangan gizi buruk (Depkes RI, 2002).

Imunisasi merupakan tindakan yang efektif untuk mencegah suatu penyakit. Seorang bayi perlu mendapat delapan kali suntikan untuk imunisasi lengkap yaitu BCG satu kali, DPT tiga kali, Polio empat kali, $\mathrm{Hb}$ tiga kali dan campak satu kali (Depkes RI, 2003).

Dalam sosialisasi dan lokakarya program peningkatan cakupan imunisasi di provinsi Jawa Tengah menyatakan bahwa kesadaran untuk memberikan imunisasi pada balita masih rendah, yaitu terjadi penurunan cakupan imunisasi di beberapa daerah di Indonesia. Fakta ini didasarkan pada peningkatan jumlah penderita penyakit yang seharusnya dapat dicegah dengan imunisasi seperti campak dan polio.

Hepatitis B adalah penyakit yang dapat merusak hati. Penyakit ini dapat berlangsung lama dan menjadi berat. Dan beberapa penyakit hati akibat virus yang paling berbahaya adalah Hepatitis B. Pada saat ini diperkirakan diseluruh dunia terpadat 216 juta orang carrier Hepatitis B. Di Indonesia sendiri sebagaimana dilaporkan oleh beberapa ahli bahwa tersangka Hepatitis B sekitar 17, 78\%, 
JOURNAL OF NURSING PRACTICE AND EDUCATION

VOL. 01 NO. 02, JUNI 2021

DOI: $10.34305 /$ JNPE.V1I2.294
Ciptaan disebarluaskan di bawah

Lisensi Creative Commons Atribusi-

NonKomersial-BerbagiSerupa 4.0 Internasional. ironisnya sampai saat ini belum ada pengobatan yang mampu menyembuhkan hepatitis B. Imunisasi hepatitis B cukup efektif untuk mencegah penyakit hepatitis B dan tentunya juga mencegah kanker hati (Rampengan, 2008).

Beberapa faktor yang mempengaruhi pemberian imunisasi diantaranya :

Sosial ekonomi, Pendidikan formal, Tingkat pengetahuan, Umur, Pekerjaan, Frekuensi ANC, Penolong persalinan, Dukungan keluarga

Diantara faktor tersebut di atas, faktor dukungan keluarga dan pengetahuan yang lebih dominan. Agar orang tua khususnya ibu bayi dapat melakukan perannya dengan baik dalam memberikan imunisasi hepatitis B pada bayi umur $0-7$ hari, maka dibutuhkan dukungan keluarga dan pengetahuan yang cukup serta memadai tentang bahaya penyakit hepatitis B, cara penularannya, dan cara pencegahannya. Serta adanya pembinaan dan penyuluhan oleh tenaga kesehatan kepada ibu bayi mengenai imunisasi hepatitis B.

Menurut data yang diperoleh dari Dinas Kesehatan Kabupaten Brebes Tahun 2010, jumlah bayi sebanyak 33.348 bayi, yang di imunisasi HBo sebanyak 24.528 bayi atau sekitar 74,6 \% dari target 94,2\%
Di Kecamatan Sirampog Kabupaten Brebes Tahun 2010 terdapat jumlah bayi sebanyak 2.125 bayi, yang di imunisasi HBo sebanyak 880 bayi atau sekitar 41,4 \%. Di Desa Igirklanceng sendiri jumlah bayi 40 bayi dan yang di imunisasi HBo sebanyak 30 bayi sekitar $75 \%$ (Dinas Kesehatan Kabupaten Brebes, 2010) .

Berdasarkan gambaran latar belakang tersebut di atas peneliti tertarik untuk melakukan penelitian dengan judul "Hubungan Antara Dukungan Keluarga dan Pengetahuan Ibu Bayi dengan Pemberian Imunisasi HBo di Desa Igirklanceng Kecamatan Sirampog Kabupaten Brebes Tahun 2020".

\section{Rumusan Masalah}

Berdasarkan latar belakang yang telah diuraikan, yang menjadi rumusan dalam penelitian ini adalah "Adakah Hubungan Antara Dukungan Keluarga dan Pengetahuan Ibu Bayi dengan Pemberian Imunisasi HBo di Desa Igirklanceng Kecamatan Sirampog Kabupaten Brebes Tahun 2020 ?".

\section{Metodologi Penelitian}

\section{Lokasi dan Waktu Penelitian}

\section{Lokasi}

Adapun lokasi penelitian dilaksanakan di Desa Igirklanceng Kecamatan Sirampog Kabupaten Brebes dan 
JOURNAL OF NURSING PRACTICE AND EDUCATION

VOL. 01 NO. 02, JUNI 2021

DOI: $10.34305 /$ JNPE.V1I2.294

waktu penelitian dilakukan mulai bulan Januari sampai dengan bulan Mei tahun 2020 .

\section{Waktu penelitian}

Waktu penelitian dilakukan mulai bulan Januari sampai dengan bulan Mei tahun 2020.

\section{Jenis dan Rancangan Penelitian}

Dalam penelitian ini penulis menggunakan jenis penelitian Cross sectional dimana obyek penelitian hanya dilihat satu kali. Pendekatan yang digunakan dalam penelitian ini adalah dengan menggunakan korelasional dengan tujuan untuk mengetahui hubungan antara dukungan keluarga dan pengetahuan ibu bayi dengan pemberian imunisasi.

Keeratan hubungan didasarkan pada koefisien korelasi yang diperoleh dari setiap variabel penelitian yang dianalisis.

\section{Populasi dan Teknik Sampling}

\section{Populasi}

Menurut Badriah (2012), populasi adalah kelompok subjek yang hendak dikenai generalisasi hasil penelitian. Populasi dalam penelitian ini adalah seluruh ibu bayi yang berdomisili di desa Igirklanceng Kecamatan Sirampog Kabupaten Brebes pada bulan Januari sampai dengan Mei 2020 sebanyak 43 orang.

\section{Sampel dan Teknik sampling}

Ciptaan disebarluaskan di bawah

Lisensi Creative Commons Atribusi-

NonKomersial-BerbagiSerupa 4.0 Internasional.

Sampel adalah sebagian objek yang diambil dari keseluruhan objek yang diteliti dan dianggap mewakili seluruh populasi (Notoatmodjo, 2014). Metode pengambilan pada penelitian ini menggunakan total sampling.

Menurut Badriah (2012), total sampling dilakukan pada penelitianpenelitian kasus yang spesifik dan sangat homogen karakteristik dan populasinya, biasanya kurang dari 30. Sampel dalam penelitian ini adalah ibu bayi di Desa Igirklanceng yang berjumlah 43 orang.

\section{Variabel Penelitian}

Penelitian ini menggunakan variabel bebas dan variabel terikat. Dalam penelitian ini yang dijadikan variabel bebas adalah dukungan keluarga dan pengetahuan tentang imunisasi HBo. Sedangkan variabel terikatnya adalah pemberian imunisasi HBo.

\section{Instrumen Penelitian}

Menurut Badriah (2012) bahwa instrument adalah pengumpulan data yang telah baku atau alat pengumpulan data yang memiliki standar validitas dan reliabilitas. Pengumpulan data dilakukan dengan mencatat semua data yang diperlukan dari laporan buku laporan bulanan dalam 1 tahun Puskesmas Brebes. pada tahun 2019 dengan menggunakan format isian yang berisi daftar isian tentang variabel-variabel yang diteliti

E-ISSN 2623-1204 P-ISSN 2252-9462 | 114 
JOURNAL OF NURSING PRACTICE AND EDUCATION

VOL. 01 NO. 02, JUNI 2021

DOI: $10.34305 / J N P E . V 1 I 2.294$
Ciptaan disebarluaskan di bawah

Lisensi Creative Commons Atribusi-

NonKomersial-BerbagiSerupa 4.0

Internasional. (format terlampir) yang meliputi nomor, nama, umur, paritas, UK, status gizi, BBLR / tidak BBLR.

\section{Teknik Pengumpulan Data}

Menurut Badriah (2012), Instrumen adalah alat pengumpulan data yang telah baku atau alat pengumpulan data yang memiliki standar validitas dan reliabilitas.
Alat pengumpulan data yang digunakan penulis dalam penelitian ini adalah menggunakan kuesioner sebanyak 20 pertanyaan tertutup. Menurut Badriah (2012), kuesioner pilihan ganda atau kuesioner tertutup adalah semua jawaban pilihan yang telah disediakan oleh peneliti.

Tabel 1.1 Kisi - Kisi Kuesioner Pengetahuan Ibu Bayi Tentang Pemberian Imunisasi HBo

\begin{tabular}{lcc}
\hline \multicolumn{1}{c}{ Indikator } & Nomor Item & Jumlah Item \\
\hline Pengertian imunisasi & $1,5,6,7,13,14,15,16,19,20$ & 10 \\
Tujuan imunisasi & $2,3,4$ & 3 \\
Cara pemberian imunisasi & $8,9,10,11,12,17,18$ & 7 \\
\hline \multicolumn{1}{c}{ Jumlah item pertanyaan } & & $\mathbf{2 0}$ \\
\hline
\end{tabular}

Metode Pengolahan dan Rancangan Analisis Data

\section{Pengolahan Data}

Data-data yang akan diperoleh sebelum dianalisis akan diolah melalui tahap-tahap pengolahan data sebagai berikut:

\section{Editing}

Editing adalah Melaksanakan pemeriksaan data yang diperoleh yang meliputi kebenaran pengisian, kelengkapan jawaban, konsistensi dan relevansi jawaban terhadap daftar pertanyaan yang diberikan.

\section{Coding dan Scoring}

Coding adalah memberikan kode dan mengklasifikasi data pada masing-masing jawaban untuk mempermudah pengolahan data, dimana kode yang digunakan sekaligus sebagai skor (skoring).

\section{Tabulating}

Tabulasi adalah mengelompokan data-data yang telah diperoleh sesuai dengan karakteristik pertanyaan untuk mendapatkan gambaran statistik mengenai distribusi nilai dari data sehingga sifat data yang diinginkan dapat diketahui.

\section{Entry Data}

Menurut Budiarto (2001), Merupakan suatu proses pemasukan data kedalam komputer untuk selanjutnya dilakukan analisis.

\section{Analisis Data}

E-ISSN 2623-1204 P-ISSN 2252-9462 | 115 
JOURNAL OF NURSING PRACTICE AND EDUCATION

VOL. 01 NO. 02, JUNI 2021

DOI: $10.34305 /$ JNPE.V1I2.294
Ciptaan disebarluaskan di bawah

Lisensi Creative Commons Atribusi-

NonKomersial-BerbagiSerupa 4.0 Internasional
Analisa data dilakukan secara bertahap yaitu secara univariat dan analisis bivariat, analisa diolah dengan menggunakan komputer.

\section{Analisa Univariat}

Analisa data yang digunakan dalam penelitian ini adalah analisis univariat menggunakan distribusi frekuensi dengan cara mengubah tiap kelas dalam bentuk persen $(\%)$.

Menurut Arikunto (2011), hasil yang diperoleh kemudian dimasukkan ke dalam kategori :

Kategori baik apabila pertanyaan yang dijawab dengan benar oleh responden sebanyak > 75\% - $100 \%$.

Kategori cukup apabila pertanyaan yang dijawab dengan benar oleh responden sebanyak $60 \%-75 \%$.

Kategori kurang apabila pertanyaan yang dijawab dengan benar oleh responden sebanyak $<60 \%$.

\section{Analisa Bivariat}

Analisa bivariat dilakukan untuk melihat data variabel yaitu variabel bebas dan variabel terikat yang diduga berhubungan erat dengan menggunakan uji statistik chi square (X2).

Digunakan uji chi square (X2) karena dilihat dan segi data, penelitian ini bermaksud untuk mengetahui hubungan antara variabel yang diteliti.

Menurut Badriah (2012), Statistik non parametrik digunakan untuk menguji hipotesis bila datanya berbentuk nominal dan ordinal, dan tidak berlandaskan asumsi bahwa distribusi data harus normal.

Menurut Fajar et al., (2009), uji non parametrik menggunakan rumus chi square atau X2 yaitu :

$$
x^{2}=\sum \frac{(o i j-E i j)^{2}}{E i j}
$$

Keterangan :

Oij = Jumlah observasi pada kasus-kasus yang dikategorikan dalam baris ke-1 dalam ke-j.

Eij = Jumlah kasus yang diharapkan yang dikategorikan dalam baris ke-1 dalam kolom ke-j.

Untuk melihat adanya korelasi dilakukan dengan membandingkan harga chi-square hitung dengan chi-square tabel, dengan tingkat kepercayaan 0,05 dan $\mathrm{CI}$ 95\% ( $\alpha=0,05)$. Kriteria pengujian Untuk dapat memberikan interpretasi terhadap koefisien korelasi dihasilkan, penulis berpedoman pada ketentuan yang tertera pada tabel sebagai berikut :

Tabel 1.2 Pedoman Untuk Memberikan Interpretasi Terhadap Koefisien Korelasi 


\begin{tabular}{cc}
\hline Interval koefisien & Tingkat hubungan \\
\hline $0,000-0,199$ & Sangat rendah \\
$0,200-0,399$ & Rendah \\
$0,400-0,599$ & Sedang \\
$0,600-0,799$ & Kuat \\
$0,800-1,000$ & Sangat kuat
\end{tabular}

\section{Hasil Penelitian}

Sumber : Sugiyono (2016)

\section{Analisa Univariat}

\section{Dukungan Keluarga}

Tabel 1.3 Distribusi Frekuensi Dukungan Keluarga Pada Ibu Bayi di Desa Igirklanceng Kecamatan Sirampog Kabupaten Brebes Tahun 2020.

\begin{tabular}{ccc}
\hline Dukungan Keluarga & Frekuensi & Persentase (\%) \\
\hline Tidak mendukung & 22 & 51,2 \\
Mendukung & 21 & 48,8 \\
\hline Total & $\mathbf{4 3}$ & $\mathbf{1 0 0 , 0}$ \\
\hline
\end{tabular}

Berdasarkan tabel menunjukkan responden $(51,2 \%)$, dan responden yang bahwa, keluarga responden yang tidak mendukung yaitu sebanyak 21 responden mendukung imunisasi adalah sebanyak $22 \quad(48,8 \%)$.

\section{Pengetahuan}

Tabel 1.4 Distribusi Frekuensi Pengetahuan Tentang Imunisasi Hbo Pada Ibu Bayi di Desa Igirklanceng Kecamatan Sirampog Kabupaten Brebes Tahun 2020

\begin{tabular}{ccc}
\hline $\begin{array}{c}\text { Pengetahuan Tentang } \\
\text { Imunisasi HBo }\end{array}$ & Frekuensi & Persentase (\%) \\
\hline Kurang & 7 & 16,3 \\
Cukup & 21 & 48,8 \\
Baik & 15 & 34,9 \\
\hline Total & $\mathbf{4 3}$ & $\mathbf{1 0 0 , 0}$ \\
\hline
\end{tabular}


JOURNAL OF NURSING PRACTICE AND EDUCATION

VOL. 01 NO. 02, JUNI 2021

DOI: $10.34305 / J N P E . V 1 I 2.294$
Ciptaan disebarluaskan di bawah

Lisensi Creative Commons Atribusi-

NonKomersial-BerbagiSerupa 4.0 Internasional.

Berdasarkan tabel menunjukkan responden yang memiliki pengetahuan baik bahwa, pengetahuan tentang imunisasi $\mathrm{HBo}$ ibu bayi responden yang berpengetahuan cukup yaitu sebanyak 21 responden $(48,8 \%)$, sebanyak 15 responden $(34,9 \%)$ dan responden yang berpengetahuan kurang adalah 7 responden $(16,3 \%)$.

\section{Pemberian Imunisasi HBo}

Tabel 1.5 Distribusi Frekuensi Pemberian Imunisasi Hbo Pada Ibu Bayi di Desa Igirklanceng Kecamatan Sirampog Kabupaten Brebes Tahun 2020.

\begin{tabular}{ccc}
\hline Pemberian Imunisasi HBo & Frekuensi & Persentase (\%) \\
\hline Tidak diberikan & 20 & 46,5 \\
Diberikan & 23 & 53,5 \\
\hline Total & $\mathbf{4 3}$ & $\mathbf{1 0 0 , 0}$ \\
\hline
\end{tabular}

Berdasarkan tabel menunjukkan bahwa, pemberian imunisasi HBo ibu bayi responden yang tidak diberikan yaitu sebanyak 20 responden $(46,5 \%)$, dan responden yang diberikan yaitu sebanyak 23 responden $(53,5 \%)$.

\section{Analisa Bivariat}

\section{Hubungan Antara Dukungan Keluarga Dengan Keputusan Pemberian Imunisasi HBo.}

Tabel 1.6 Hubungan Antara Dukungan Keluarga Dengan Keputusan Pemberian Imunisasi Hbo di Desa Igirklanceng Kecamatan Sirampog Kabupaten Brebes Tahun 2020.

\begin{tabular}{|c|c|c|c|c|c|c|c|}
\hline \multirow{3}{*}{$\begin{array}{c}\text { Dukungan } \\
\text { keluarga }\end{array}$} & \multicolumn{6}{|c|}{ Pemberian imunisasi HBo } & \multirow{3}{*}{ Ket } \\
\hline & \multicolumn{2}{|c|}{ Tidak } & \multicolumn{2}{|c|}{ Ya } & \multicolumn{2}{|c|}{ Total } & \\
\hline & $\mathbf{F}$ & $\%$ & $\mathbf{F}$ & $\%$ & $\mathbf{F}$ & $\%$ & \\
\hline $\begin{array}{c}\text { Tidak } \\
\text { mendukung }\end{array}$ & 19 & 44,2 & 3 & 7,0 & 22 & 51,2 & \multirow{2}{*}{$\begin{array}{c}r=0,818 \\
p=0,00063\end{array}$} \\
\hline Mendukung & 1 & 2,3 & 20 & 46,5 & 21 & 48,8 & \\
\hline Total & 20 & 56,7 & 23 & 43,3 & 43 & 100,0 & \\
\hline
\end{tabular}


JOURNAL OF NURSING PRACTICE AND EDUCATION

VOL. 01 NO. 02, JUNI 2021

DOI: $10.34305 / J N P E . V 1 I 2.294$

Berdasarkan tabel dapat dijelaskan bahwa, pada responden yang tidak mendapatkan dukungan keluarga yaitu sebanyak 19 responden $(44,2)$ tidak diberikan imunisasi HBo dan pada responden yang mendapat dukungan dari keluarga yaitu sebanyak 20 responden (46,5\%) diberikan imunisasi HBo.
Ciptaan disebarluaskan di bawah Lisensi Creative Commons AtribusiNonKomersial-BerbagiSerupa 4.0 Internasional
Berdasarkan hasil uji statistik chi kuadrat diperoleh nilai $\mathrm{p}=0,00063<\alpha$ $(0,05)$ hal ini menunjukkan bahwa Ho ditolak Ha diterima yang berarti ada hubungan signifikan antara dukungan keluarga dengan keputusan pemberian imunisasi HBo di Desa Igirklanceng Kecamatan Sirampog Kabupaten Brebes tahun 2020.

Hubungan Antara Pengetahuan Dengan Keputusan Pemberian Imunisasi HBo.

Tabel 1.7 Hubungan Antara Pengetahuan Dengan Keputusan Pemberian Imunisasi HBo di Desa Igirklanceng Kecamatan Sirampog Kabupaten Brebes Tahun 2020.

\begin{tabular}{cccccccc}
\hline & \multicolumn{6}{c}{ Pemberian imunisasi HBo } \\
\cline { 2 - 7 } $\begin{array}{c}\text { Pengetahuan Tentang } \\
\text { Imunisasi HBo }\end{array}$ & \multicolumn{2}{c}{ Tidak } & \multicolumn{2}{c}{ Ya } & \multicolumn{2}{c}{ Total } & \multirow{2}{*}{ Ket } \\
\cline { 2 - 7 } & F & \% & F & \% & F & \% & \\
Kurang & 7 & 16,3 & & & 7 & 16,3 & \\
Cukup & 10 & 23,3 & 11 & 25,6 & 21 & 48,8 & r=0,509 \\
Baik & 3 & 7,0 & 12 & 27,9 & 15 & 34,9 & \\
\hline Total & $\mathbf{2 0}$ & $\mathbf{5 6 , 7}$ & $\mathbf{2 3}$ & $\mathbf{4 3 , 3}$ & $\mathbf{4 3}$ & $\mathbf{1 0 0 , 0}$ & \\
\hline
\end{tabular}


JOURNAL OF NURSING PRACTICE AND EDUCATION

VOL. 01 NO. 02, JUNI 2021

DOI: $10.34305 /$ JNPE.V1I2.294
Ciptaan disebarluaskan di bawah

Lisensi Creative Commons Atribusi-

NonKomersial-BerbagiSerupa 4.0 Internasional
Berdasarkan tabel dapat dijelaskan bahwa, pada responden yang mempunyai pengetahuan kurang seluruhnya tidak memberikan imunisasi $\mathrm{HBo}$, responden yang mempunyai pengetahuan cukup yaitu sebanyak 11 responden $(25,6 \%)$ memberikan imunisasi HBo (25,6\%), dan responden yang mempunyai pengetahuan baik yaitu sebanyak 12 responden memberikan imunisasi $\mathrm{HBo}(27,9 \%)$.

Berdasarkan hasil uji statistik chi kuadrat diperoleh nilai $\mathrm{p}=0,005<\alpha(0,05)$ hal ini menunjukkan bahwa Ho ditolak Ha diterima yang berarti ada hubungan antara pengetahuan dengan keputusan pemberian imunisasi $\mathrm{HBo}$ di Desa Igirklanceng Kecamatan Sirampog Kabupaten Brebes Tahun 2020.

\section{Pembahasan}

Hubungan Antara Dukungan Keluarga Dengan Keputusan Pemberian Imunisasi HBo di Desa Igirklanceng Kecamatan Sirampog Kabupaten Brebes Tahun 2020.

Berdasarkan hasil uji statistik chi kuadrat diperoleh nilai $\mathrm{p}=0,00063<\alpha$ $(0,05)$ hal ini menunjukkan bahwa Ho ditolak $\mathrm{Ha}$ diterima yang berarti ada hubungan signifikan antara dukungan keluarga dengan keputusan pemberian imunisasi $\mathrm{HBo}$ di Desa Igirklanceng Kecamatan Sirampog Kabupaten Brebes Tahun 2020.

Program imunisasi hepatitis B di Bengkulu sudah dilaksanakan sejak Januari 2000. Namun angka kelengkapan imunisasi hepatitis B masih $74,94 \%$ dan pada tahun 2007 sebesar 74,88\%. Angka kelengkapan imunisasi yang paling rendah adalah di Puskesmas Tapus, yaitu 45,5\%. Angka ini jauh dibawah rata - rata angka Kabupaten Lebong $78,56 \%$. Penelitian ini bertujuan untuk mengetahui faktor - faktor yang berhubungan dengan status imunisasi hepatitis B di Puskesmas Tapus Kabupaten Lebong.

Keluarga berfungsi sebagai sebuah kolektor dan diseminator (penyebar) informasi tentang dunia. Menjelaskan tentang pemberian saran, sugesti, informasi yang dapat digunakan mengungkapkan suatu masalah. Manfaat dari dukungan ini adalah dapat menekan munculnya suatu stressor karena informasi yang diberikan dapat menyumbangkan aksi sugesti yang khusus pada individu. Aspek-aspek dalam dukungan ini adalah nasehat, usulan, saran, petunjuk dan pemberian informasi.

Dukungan keluarga dapat berupa dukungan informasi, emosional dan 
JOURNAL OF NURSING PRACTICE AND EDUCATION

VOL. 01 NO. 02, JUNI 2021

DOI: $10.34305 /$ JNPE.V1I2.294
Ciptaan disebarluaskan di bawah

Lisensi Creative Commons Atribusi-

NonKomersial-BerbagiSerupa 4.0 Internasional. ekonomi. Dukungan emosional dalam keluarga mempunyai peranan penting untuk meningkatkan harga diri individu dan motivasi untuk mempraktikkan sesuatu yang diketahuinya. Sedangkan dukungan ekonomi adalah berupa biaya atau dana untuk membiayai pemeriksaan atau imunisasi bagi bayi.

\section{Hubungan Antara Pengetahuan Dengan}

Keputusan Pemberian Imunisasi HBo di Desa Igirklanceng Kecamatan Sirampog Kabupaten Brebes Tahun 2020.

Berdasarkan hasil uji statistik chi kuadrat diperoleh nilai $\mathrm{p}=0,005<\alpha(0,05)$ hal ini menunjukkan bahwa Ho ditolak $\mathrm{Ha}$ diterima yang berarti ada hubungan antara pengetahuan dengan keputusan pemberian imunisasi HBo di Desa Igirklanceng Kecamatan Sirampog Kabupaten Brebes Tahun 2020.

Keinginan dalam diri seseorang yang dipengaruhi oleh pengetahuan melalui proses persepsi ini ditentukan kepribadian, sikap, pengalaman dan harapan seseorang. Selanjutnya apa yang diterima tersebut diberi arti oleh yang bersangkutan menurut minat dan keinginannya. Motivasi ini mendorongnya untuk mencari informasi yang akan digunakan oleh yang bersangkutan untuk mengembangkan beberapa alternatif tindakan dan pemilihan tindakan (Notoatmodjo, 2014). Dengan demikian pengetahuan akan mempengaruhi motivasi seseorang untuk melakukan tindakan dan perilaku.

Pengetahuan merupakan salah satu yang sangat dibutuhkan dalam perubahan pola pikir dan perilaku satu kelompok masyarakat. Pengetahuan ini terkait dengan lingkungan dimana responden menetap. Keadaan lingkungan, keterpaparan media komunikasi akan mempengaruhi pengetahuan. Pengetahuan yang baik tentang imunisasi HBo akan menjadikan persepsi ibu tentang imunisasi HBo menjadi hal yang penting untuk diberikan demi kesehatan anaknya.

\section{Kesimpulan dan Saran}

\section{Kesimpulan}

Dukungan keluarga ibu bayi di Desa Igirklanceng Kecamatan Sirampog Kabupaten Brebes Tahun 2020 dari 43 responden yang tidak mendukung yaitu 22 responden $(51,2 \%)$, dan yang mendukung yaitu 21 responden $(48,8 \%)$.

Pengetahuan tentang imunisasi HBo ibu bayi di Desa Igirklanceng Kecamatan Sirampog Kabupaten Brebes Tahun 2020 dalam kategori baik 15 responden $(34,9 \%)$ dan dalam kategori cukup yaitu 21 responden $(48,8 \%)$, dan yang 
JOURNAL OF NURSING PRACTICE AND EDUCATION

VOL. 01 NO. 02, JUNI 2021

DOI: $10.34305 /$ JNPE.V1I2.294

berpengetahuan kurang yaitu 7 responden $(16,3 \%)$.

Ada hubungan antara dukungan keluarga dengan keputusan pemberian imunisasi HBo di Desa Igirklanceng Kecamatan Sirampog Kabupaten Brebes ( p $=0,00063<\alpha(0,05)$.

Ada hubungan antara pengetahuan dengan keputusan pemberian imunisasi HBo di Desa Igirklanceng Kecamatan Sirampog Kabupaten Brebes tahun $2020(p=0,005<$ $\alpha(0,05)$.

Saran

\section{Bagi Ibu}

Meningkatkan pengetahuan tentang pemberian imunisasi HBo dan Ibu yang mempunyai bayi sebaiknya memberikan imunisai HBo kepada bayinya agar bayi menjadi sehat dan mempunyai kekebalan terhadap penyakit Hepatitis B.

\section{Bagi Puskesmas}

Hendaknya Dinas Kesehatan menambah jumlah bidan desa yang bertugas di Desa Igirklanceng dan juga perlu adanya tambahan jumlah Pustu atau PKD untuk meningkatkan cakupan imunisasi khususnya imunisasi HBo.

\section{Bagi Tenaga Kesehatan}

Lebih menggencarkan promosi dengan memberikan penyuluhan dan
Ciptaan disebarluaskan di bawah

Lisensi Creative Commons Atribusi-

NonKomersial-BerbagiSerupa 4.0 Internasional.

konseling kepada ibu terutama ibu bayi agar memberikan imunisai HBo.

\section{Bagi Institusi Pendidikan}

Hendaknya melengkapi dan memperbanyak sumber - sumber pustaka sehingga dapat menambah wawasan dan memudahkan mahasiswa dalam penyusunan Karya Tulis Ilmiah yang akan datang.

\section{Daftar Pustaka}

Arikunto, S. (2011). Prosedur Penelitian Suatu Pendekatan Praktik. Jakarta: Rineka Cipta.

Badriah, D. L. (2012). Metodologi Penelitian Ilmu-Ilmu Kesehatan. Bandung: Multazam.

Budiarto, E. (2001). Biostastistik Untuk Kedokteran dan Kesehatan Masyarakat. Jakarta: EGC.

Depkes RI. (2002). Pedoman Nasional Penanggulangan Tuberkulosis. Departemen Kesehatan Indonesia, 2.

Depkes RI. (2003). Pedoman Penemuan dan Pengobatan Penderita Tuberkulosis Paru. Ditjen PPM \& PLP Depkes RI: Jakarta.

Dinas Kesehatan Kabupaten Brebes. (2010). Data Puskesmas Sirampog tahun 2010. Dinas Kesehatan Kabupaten Brebes.

Fajar, I., Isnaeni, D. T. N., Astutik, P., \& Isman, A. (2009). Statistika Untuk Praktisi Kesehatan. Yogyakarta: Graha Ilmu.

Notoatmodjo, S. (2014). Metodologi Penelitian Kesehatan. Jakarta: Rineka Cipta. 
JOURNAL OF NURSING PRACTICE AND EDUCATION VOL. 01 NO. 02, JUNI 2021

DOI: $10.34305 /$ JNPE.V1I2.294

Rampengan, T. (2008). Penyakit Infeksi Tropik Pada Anak Edisi ke-2. Jakarta: Penerbit Buku Kedokteran EGC.

Sugiyono. (2016). Metode Penelitian Kuantitatif, Kualitatif dan R\&D.
Ciptaan disebarluaskan di bawah Lisensi Creative Commons AtribusiNonKomersial-BerbagiSerupa 4.0 Internasional.

Bandung : Alfabeta.

Tangga, S. K. R. (1995). Survei Kesehatan Rumah Tangga. In Jakarta: Biro Pusat Statistik. Jakarta: Biro Pusat Statistik. 